\title{
THE INSTITUTION OF CIVIL ENGINEERS
}

\author{
WORKS CONSTRUCTION DIVISION
}

\section{DISCUSSION ON \\ "THE RELATIVE MERITS OF METHODS OF SINKING BRIDGE FOUNDATIONS"}

Session 1950-51

LONDON:

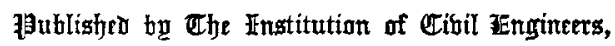

GREAT GEORGE STREET, WESTMINSTER, S.W.1

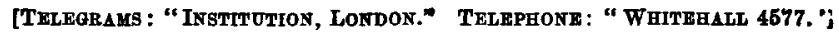

1951

The right of Publication and of Translation is reserved. 


\section{ADVERTISEMENT}

The Institution of Civil Engineers as a body is not responsible either for the statements made or for the opinions expressed in the following pages

\section{FAIR COPYING DECLARATION}

Within the terms of the Royal Society's Fair Copying Declaration, to which the Institution subscribes, material may be copied from issues of the Journal which are out of print and from which reprints are not available. The terms of the Declaration are published in Chartered Civil Engineer from time to time.

MADE AND PRINTED IN GREAT BRITAIN BY WILIIAM CLOWES AND SONS, LIMITED, LONDON AND BECCLES. 


\title{
THE INSTITUTION OF CIVIL ENGINEERS
}

\section{WORKS CONSTRUCTION DIVISION MEETING}

\author{
Tuesday, 12 December, 1950
}

David Mowat Watson, B.Sc., Vice-President I.C.E., Chairman of the Division, in the Chair

A Discussion of the subject of

\section{“The Relative Merits of Methods of Sinking Bridge Foundations"}

was held, initiated by the following Introductory Notes, and, on the motion of the Chairman, the thanks of the Division were accorded to the Authors.

Introductory Notes

(a) "Compressed Air"

by

Willifam Storey Wilson, M.C., B.Se., M.I.C.E.

(b) "Open Grabbing "

by

(a) "Compressed Air"

by

William Storey Wilson, M.C., B.Sc., M.I.C.E.

IT may be said, in general terms, that if a design for a bridge foundation involves the employment of divers, then that design is a bad one and needs revision. In other words, it is neither desirable nor necessary for the modern bridge builder to work in the dark.

Long ago, when engineers were searching for means of constructing underwater foundations, with the very limited tools and equipment available to them and before it could be established that human beings could live and work in compressed air, many expedients were tried. One of these was the monolith-a structure of great weight, sunk to its final position by grabbing out the muck immediately beneath it. It was essentially a blind operation, in the "hit-or-miss" category, and great faith, as well as a good deal of luck, was needed for success.

When the monolith structure had been sunk to a suitable depth, the voids or wells through which the muck had been removed were filled with a mixture of stone, sand, and cement-which it was hoped would become 
concrete but which probably varied throughout its mass from plain aggregate without cement to pure cement without aggregate. Upon such an unknown mixture of ingredients many important bridges have been built.

The introduction of compressed air to foundation operations on bridge works provided an alternative to the system of open grabbing. Thereafter, working in the dark became a matter of choice, not of necessity. Men could work far below river-bed-level, in comparative comfort, removing muck, boulders, or solid rock as required, and those concerned could inspect the working face at leisure and without recourse to a diving-suit.

Once sunk to a suitable depth, the pneumatic caisson could have its voids filled with concrete of a quality that could be guaranteed in advance, since the whole operation could be watched as easily as such operations are watched above ground.

There is no condition of ground or water, or both together, that cannot be dealt with by a properly designed pneumatic caisson, except the very rare case of the foundations being required to go to a depth greater than about 120 feet below the surface of the water.

Experience shows that men can work without distress in air-pressures equivalent to a hydrostatic head of 80 feet; with little distress, and for shorter periods, in air-pressures of from 80 to 110 feet head of water ; and with increased distress, and for still shorter periods, in air-pressures corresponding to depths of more than 100 feet. The practical limit of depth for compressed-air working has not been established, but, for reasons of economy alone, it may be regarded as being not more than 120 feet.

Fortunately, Nature herself ensures that compact conditions of one kind or another are found at moderate depths. In almost all cases, suitable foundations for bridge piers can be established at a depth of from 40 to 80 feet below the bed of the waterway. Exceptions to this condition are so rare that if the designer meets with them he is provided with a good excuse for moving his bridge to another site!

It may be said, therefore, that the compressed-air caisson can be used in almost any circumstances that are found in Nature.

It has been suggested that compressed-air caissons should be avoided whenever possible because they are more expensive than open-well monoliths.

Estimates may furnish some guide in comparing costs with the two types of construction; but it can be said that the ratio of the estimated cost to the real cost of a compressed-air caisson is likely to be much closer to unity that it can ever be with the system of open grabbing. The contractor's estimator knows quite accurately what a compressed-air caisson is likely to cost to build and to sink ; but he is bowed down with reservations and margins when considering an open-grabbing project.

Many engineers and contractors in the past have looked upon compressed-air caissons with distrust because of the apparently complicated nature of the operations, of the scarcity of trained compressed-air workers, 
and also of the relative novelty of the system in comparison with general civil engineering enterprises. In reply to any such expressions of doubt, it may be said that compressed-air plant and equipment is not so complicated as a modern concrete-pumping plant, and also that experience shows that human beings can work in compressed air of moderate pressure with no discomfort and less fatigue than in the open air.

Caisson sickness in compressed-air work has been raised as a bogy more than once. Experience shows that, if men are selected carefully, general health being given more consideration than physical strength, caisson sickness will not occur more frequently than a cold in the head, and will be no more serious.

The particular merits of the compressed-air caisson for bridge foundations might be summarized as follows :--

(1) A compressed-air caisson can be sunk while maintaining verticality, position, and depth within very fine limits.

(2) Any boulders or other obstructions met with during sinking can be disposed of without undue difficulty and without recourse to the employment of divers.

(3) Where skin friction is excessive, the sinking weight can be increased by a reduction of the air-pressure in the working chamber for a short period.

(4) The strata through which the caisson is sunk are available for inspection throughout, and a considered decision can accordingly be taken as to when the bottom is suitable for a foundation.

(5) Before placing concrete, the bottom can be cleaned up and all slurry removed.

(6) The concrete in contact with the ground which forms the foundation to the bridge pier is placed in the dry.

(7) After the concrete has been placed it can be grouted, under pressure, and all interstices filled.

Not one of the above-mentioned merits, with the possible exception of the last, is common to the monolith sunk by open grabbing; to forego them and, at the same time, to invite construction difficulties-some of which are referred to below-passes all understanding! It is right that the young engineer should be warned of these difficulties and that the older engineers who have encountered them should disclose their experienceseven if that brings back hateful memories believed to be long since buried.

The monolith must have weight, to overcome skin friction and the bearing value of the ground below the cutting edge ; it must also have a hole or holes sufficiently large to accommodate the grab.

To obtain sufficient weight, the thickness of concrete around the hole or well must be the maximum; but the greater it is the greater also is the ledge of undisturbed ground below it which cannot be touched by 
the grab. The weight of the monolith must not only overcome the skin friction, but also break down this ledge of undisturbed ground. In practice, particularly for smaller monoliths, it is found that kentledge has to be built on the top of the monolith, and, when this added weight is not sufficient to cause settlement, pumping is resorted to within the well to reduce buoyancy, with an inevitable inflow of material from outside the cutting edge. When the maximum weight of kentledge and a safe amount of pumping produce no settlement, grabbing, as a last resort, proceeds until a hole has been dug many feet below the level of the cutting edge. Sooner or later, the stage is reached when the ledge below the cutting edge fails, the surrounding material falls into the hole which has been grabbed, and the monolith plunges downwards many feet until arrested, usually, by the transfer of the weight of the overhanging kentledge from the monolith to the surrounding ground or staging.

Its position when arrested is a matter of luck-not of control. The kentledge is removed and stacked alongside, and the weary business of carrying the concrete up another 15 feet or so, building the kentledge in position again, and continuing the grabbing until the monolith makes its next plunge downwards is repeated.

With painstaking patience and perseverance, the monolith ultimately reaches the more or less required level, with a verticality and position over which the engineer-in-charge has had no control whatever.

If, on one of its downward plunges, the cutting edge should happen to encounter a boulder or other obstruction, the monolith lurches out of plumb and, as likely as not, the kentledge is shot off on to the ground or into the river.

This is the stage when the real trouble starts; and those who have not experienced it must just use their imagination. Divers proceed to remove the obstruction by blasting; a great hole is grabbed at one side, into which it is hoped to "persuade" the monolith with some degree of verticality, by means of jacks and struts, eccentrically built kentledge, and anything else which comes to mind. In due course, the monolith is pronounced founded.

The next process, as required by the Specification, is to clean up the bottom by diver, and place a concrete seal under water. The well might just as well be filled with sand, for the monolith will never move: the problem throughout has been to make it do so!

It is at this stage that the cost is counted; and the estimate begins to look rather silly.

Anyone who makes an estimate for the construction of a bridge which includes piers sunk by open grabbing is an optimist if he secures the contract-and a lucky man if he does not.

The Agent in charge of the construction of such a bridge requires a big heart, and should be devoid of all pessimistic tendencies when he starts, whatever he may be when he finishes the job. 
When a case has been made out for sinking the caisson under compressed air, it should not be assumed that this is always easy. There can be more than one set of conditions which make sinking very difficult indeed. One case in particular is that where the caisson is sited on a river bank and the material to be passed through has little or no shear value; where the tidal range is high, giving a considerable variation in the sinking weight between high and low water; and where there is little resistance to the tendency for the caisson to move riverwards during sinking.

But, however adverse these conditions may be for a compressed-air caisson, they are infinitely worse, if not impossible, in the case of a monolith.

(b) "Open Grabbing"

by

Hubert Shirley Smith, O.B.E., B.Sc.(Eng.), M.I.C.E.

\section{INTRODUCTION}

THE purpose of these notes is to set down the methods of sinking cylinders or monoliths by means of open grabbing, to observe the limitations of the process, and to discuss its advantages and disadvantages in comparison with sinking by means of compressed air. Reference is also made to the combination of the two methods, by which cylinders may be sunk partly by open dredging and partly under compressed air. To avoid confusion, it is proposed to call the foundations " monoliths" when they are designed to be sunk by open grabbing and "caissons" when they are intended for compressed-air working.

\section{The Method}

The method of open grabbing is very well known and has been extensively used, particularly in sinking the foundations of many great bridges overseas.

The muck is grabbed out through one or more shafts or wells in the monolith, which then sinks under its own weight. If the ground is permeable, water enters the shafts and the muck is dredged out through the water. The side walls are built up in the usual way as the monolith sinks. For many Indian bridges of the past century, the practice was to build the wells of brick or stone, which was readily obtainable and easy to place, and bridges founded on brick wells in the sand may be found all over India. More recent practice has been to use concrete or reinforcedconcrete steining for the monoliths.

When founding-level is reached, the water in the shafts may be pumped 
out a little, to reduce the buoyancy of the monolith and so force the cutting edge well into the ground. The amount of dewatering must be strictly limited in built-up areas, particularly if the foundation is in permeable material; otherwise muck may enter the shaft from outside.

Before plugging, sand may be dropped through the water in the shaft to form a level bed a foot or two above the cutting edge. Sand deposited in this way compacts into a solid mass with a hard smooth surface. Alternatively, the conerete plug may be deposited straight away. The concrete has, of course, to be placed under water, either by lowering it in bottom-opening skips or through a tremie pipe. After the monolith has been plugged at the bottom, the shafts may be filled with water, sand, or concrete to the underside of the concrete cap at the top, which can be deposited in the dry.

There is little difference in design between small monoliths and caissons with only one or two shafts, except that in the monoliths no working chamber is required nor is any provision needed for attaching air-shafts or locks. Between large monoliths and caissons there are considerable differences. In the monolith, it is essential to provide dredging shafts at not more than (say) 20 -foot centres over the whole area ; in a large monolith twenty shafts may be required. In a caisson of the same size, however, the excavation can be carried out at a distance from the shaft and only about six working chambers would be needed, each with its air-shaft and lock. In all monoliths it is desirable to keep the walls as thin as possible at the bottom and the cutting edges long and straight, so far as is practicable, in order to assist the sinking.

Limitations.-The ground must be suitable for grabbing-sand, alluvial deposits, silt, or some kinds of gravel and not too hard clay. Many rivers have deep alluvial deposits in the bed and the conditions suitable for open dredging are found widely distributed throughout the world. If the material is very soft and easily disturbed by water, such as silt under artesian head, grabbing is inadvisable; under such conditions, pneumatic sinking is preferable because the pressure of the compressed air is probably needed to hold the caisson up in the early stages of sinking and keep the muck from flowing in.

Obstructions such as old foundations must be removed before the monolith is pitched; this would generally be desirable, although not essential, when sinking a caisson.

The great advantage of open dredging is that there is no limit to the depth at which the method can be used; bridge piers have been sunk to a depth of 228 feet below water-level. The depth to which caissons can be sunk under air is limited to about 120 feet. For deeper foundations, open dredging is the only possible system.

Ground with layers of hard strata is also unsuitable for grabbing, since the addition of kentledge may be necessary to sink the monolith; that is always a tedious matter. Sinking into rock by dredging has, until 
recently, been considered impracticable, but it was done successfully at a depth of 216 feet in the foundation for the twin anchorage of the San Francisco-Oakland Bay bridge. There is also on record a labour of Hercules that was performed in founding the piers of the Natravarti bridge at Mangalore, India, in 1905. In that job, the wells were sunk 60 feet through sand and muck by open dredging and were founded on rock which was levelled off by divers.

Advantages.-(1) Very little plant is required for open grabbing and it is all of the simplest kind - a crane and grabs, with somewhere to dump the excavated material if it is not permitted to put it back into the river. None of the elaborate compressed-air plant is required, comprising air compressors (in duplicate), receivers, air locks, shafts, recompression chamber, valves and piping, etc.

(2) Less skilled and experienced supervision is required than for pneumatic sinking and there is therefore a bigger field of choice when trying to find staff. A less rigorous medical check is needed for both staff and labour. Much less labour is required (a very important point today), since the excavation is wholly mechanized and no sinkers or labourers are needed for digging.

(3) Open grabbing is safer for the men employed than pneumatic sinking. There is no risk of caisson disease or "bends" and the number of casualties is very much less.

(4) Sinking by open grabbing is quicker than by compressed air. The: time occupied in installing the compressed-air plant, erecting the air-shafts, locks, etc., and extending the shaft as sinking proceeds is saved. The grabs can have a capacity up to 100 cubic feet, which is three times the size of the biggest bucket used in compressed-air work (33 cubic feet). Moreover, under good conditions, about fifteen grab-loads could be taken out per hour, as against ten bucket-loads at the best through the air-lock.

(5) Open dredging is therefore more economical than compressed-airwork, the principal savings in cost being as follows :-

(a) Less plant and a less costly type of plant.

(b) Less skilled supervision and a smaller labour force.

(c) Quicker sinking.

The cost per foot of foundations sunk by open grabbing for the Lower Zambezi bridge is stated to have been less than one-third the cost of those sunk under compressed air.

Disadvantages.-(1) Monoliths may offer more resistance to sinking in stiff ground than caissons. The reason for this is that the grabs will not excavate closer than about 2 feet to the cutting edge, and it is difficult to get them into rectangular corners. Water jets can be used for squirting inside the shaft to soften the material below the cutting edge and in the corners, as was tried in the Hawkesbury River railway bridge. Water or 
air jets can also be used outside to break down the skin friction, but this may permanently destroy a useful source of support for the foundation.

In order to assist sinking, skin friction may be momentarily broken down in a small monolith by firing a shot in the water in the shaft ; undercutters can also be used to slice the ground beneath the cutting edge to enable the monolith to break through it.

(2) The buoyancy of the monolith can also be reduced by dewatering to a small extent, although this must be done with due care in built-up areas in order to avoid material entering the shaft from outside. Obviously no settlement of the ground is permissible close to other buildings. In remote places, however, there is no great objection to it. The system of "running the wells" has been extensively used in India. There it has been employed in sinking deep wells through river beds that are scoured away to a depth of 50 to 100 feet every year in the flood season; and if the sand is going to be swept away bodily and replaced every year there can be little harm in disturbing it during sinking. It should be noted also that, if the well is allowed to fill with water and is not pumped, the pressure on the base of the shaft keeping the muck out will be the same as the pressure that would be exerted by the air in a caisson.

(3) It may be suggested that concrete deposited under water is not so good as concrete placed in the dry and that the foundation cannot be cleaned up and examined, except by diver, before the concrete is placed. There is not much in this argument, because excellent concrete can be placed under water, if proper precautions are taken ; it is a method widely adopted in important works today. In any case, theoretically, the concrete need only be equal in strength to the ground on which it is placed.

The concrete plug has to bear less load if placed in a monolith sunk by open grabbing; for the weight of the monolith, as then constructed (less skin friction and buoyancy), is borne by the material beneath the cutting edge and the concrete plug has to carry only the weight of the foundation added subsequently plus the reaction from the superstructure. In a caisson, all the material is excavated from beneath the cutting edge and the plug has to carry the whole weight of the foundation (less buoyancy and skin friction) plus the reaction from the superstructure.

(4) It is admittedly more difficult to control small monoliths with only one or two wells if they are sunk by open dredging than if compressed air be used. But if care be taken to correct at once any tendency to tilt in the first 30 feet of sinking, the monoliths will thereafter usually not be difficult to keep in position. This fact was exemplified in the Lower Zambezi bridge where, of twenty-seven monoliths, only two were more than 3 inches out of position, the maximum deviation being $6 \frac{1}{8}$ inches. Large monoliths with four or more wells present no difficulty in control.

Combination of Open Grabbing and Compressed Air.-As will be seen from the subsequent examples, the foundations of a number of big modern bridges have been sunk by open grabbing, but provision has been made for 
applying compressed air to any wells where it may be of assistance. This was done in the case of the Lower Zambezi, New Howrah, Silver Jubilee, and Ava bridges, with economical results. The snags that call for the use of compressed air are usually encountered in only a minority of the foundations. Thus by this method the economy of the open dredging system can be gained in most of the monoliths and yet the assistance of compressed air is available for the awkward ones. In the New Howrah bridge, a great saving was made by sinking and bottoming-up all the wells of the Howrah monolith (which sealed itself in impervious ground) in the dry. This saving would have been lost if the monolith had been designed as a caisson. It would then have had only six locks and all the muck would have had to be laboriously taken out through them instead of being dredged in the open out of twenty-one wells.

Another interesting development has been the provision of compressed air to give buoyancy for floating-in or control in very soft alluvial ground, although sinking has been done by open grabbing. Bridges in which this method was successfully used include the Willingdon, the San FranciscoOakland Bay, and the New Hawkesbury River bridges.

In the ten examples given in Table 1 , it is noteworthy that although the foundations of only three bridges, the Hardinge bridge, the Bay bridge, and the New Hawkesbury River bridge were too deep for compressed air, open dredging was used in preference to pneumatic sinking, except where other conditions, such as founding in rock, made pneumatic sinking preferable.

\section{EXAMPLES}

(1) The Curzon Bridge over the River Ganges at Allahabad: No provision was made for the use of compressed air; all sinking was done by open grabbing. It was found that the brickwork steining, which weighs about $20 \mathrm{lb}$. per cubic foot less than stone or concrete, was not heavy enough to give a satisfactory preponderance of weight for sinking beyond a depth of about 70 feet. Monoliths with brick walls tended to hold up and "blow" after that depth was reached, whereas stone monoliths could be sunk 90 feet before blowing occurred. Kentledge had to be used, in conjunction with an undercutter to shift material beneath the cutting edge. A considerable volume of sand entered the wells from outside, but no settlement of the piers was observed after completion of the bridge.

(2) The Hardinge Bridge over the Lower Ganges at Sara: On account of the phenomenal depth of scour in the Ganges, estimated at 100 feet, the monoliths had to be founded 150 feet and 160 feet below low-water-level; at the time they were built these were the deepest bridge foundations in existence. There was no provision for compressed air; the monoliths were all sunk by open grabbing and suction dredging. It was found that an effective method of getting the monoliths down to the depth 
required was to " run the wells" (that is, to dewater), although the volume of sand entering from outside amounted, on an average, to about 60 per cent. of the displacement during the run. Kentledge also had to be used on about half of the monoliths.

(3) The Willingdon Bridge over the Hooghly River at Balli : All sinking was done by open grabbing, using 100-cubic-foot dredges; compressed air was used only for flotation of caissons into place before sinking. The wells were run as in the case of the Hardinge bridge. Great care had to be exercised to correct any tilt immediately; otherwise the monoliths tended to drift in the soft strata. Kentledge had to be used on some foundations. Obstructions such as old country boats and their cargoes, encountered beneath the cutting edge, were shattered by means of explosives.

(4) The Benue River Bridge at Makurdi, Nigeria: All the piers except two were founded in rock and were therefore sunk under compressed air. The two biggest and deepest piers had to be founded on sand in a chasm in the rock, but, although the depth was only 93 feet below low-water-level and compressed-air plant was working on the site, the contractors preferred to sink those monoliths by open grabbing. They experienced no difficulty in control, nor did any appreciable quantity of sand enter the wells.

(5) The Ava Bridge over the Irrawaddy River, Burma: The river bed consisted of variable depths of sand, subject to scour, overlying rock, the top of which was very uneven and disintegrated. The end pier on the Ava side was sunk to a depth of 100 feet in the sand by open grabbing. The pier next to it was founded on rock under compressed air at a depth of 80 feet below low-water-level and at that time held the record, since surpassed by the New Howrah bridge, as the deepest foundation sunk under compressed air in the East. No particular difficulties were encountered and the nine piers were maintained well in position.

(6) The Silver Jubilee Bridge over the Nerbudda River at Broach, India : The foundations consisted of twin cylinders sunk through sand and clay to a depth of 102 feet below low-water-level. Provision was made for applying compressed air if necessary but it was actually used only in the early stages of three cylinders, to correct them from tilting.

(7) The Lower Zambezi Bridge at Sena, Portuguese East Africa: Provision was made for applying compressed air to all foundations if necessary but, although the depth was nowhere greater than 123 feet below low-water-level, pneumatic sinking was used only for foundations in rock. All but six of the thirty-three big piers were sunk solely by open grabbing. There was little difficulty in control and the final position of the piers was very good. Kentledge had to be used on a minority of the foundations. The quantity of material dredged was very rarely appreciably in excess of displacement. Effective use was made of dewatering and shotfiring to break down skin friction momentarily and so to promote sinking; in one or two wells an undercutter was used with success to cut clay that was holding up the cutting edge. Measurements of the settlement of 
piers after the bridge had been in use for 3 months showed that it nowhere exceeded $\frac{25}{32}$ inch.

(8) San Francisco-Oakland Bay Bridge, California: The caisson for the twin-suspension-bridge anchorage in the west bay is the biggest yet sunk and one of the foundations for the cantilever bridge in the east bay is the deepest existing bridge foundation. The anchorage caisson was floated out and controlled by compressed air but all excavation was done by means of open grabbing. When rock was reached it was shattered, to level it off, by means of a 5-ton "gad " dropped on to it down the wells; the shattered rock was jetted out from under the cutting edges and grabbed to the surface.

The deep foundations for the cantilever bridge consisted of reinforcedconcrete monoliths with a number of square dredging-shafts : they were sunk throughout by means of open grabbing and were founded in gravel and clay.

(9) The New Howrah Bridge over the Hooghly River, Calcutta: On the Howrah side of the river, the main monolith sealed itself at once in more or less impervious ground; it was ultimately founded in 6 feet of clay and all the shafts were plugged in the open. On the Calcutta side, sinking was through mud and sand to clay; the monolith was sunk to foundinglevel by open grabbing only and the wells were plugged under compressed air. No difficulty was experienced in control. In the final stages, the middle wells had to be grabbed deep below the cutting edge, and the shafts to be dewatered to some extent to get the monolith to move, but the quantity of muck that came into the wells from outside was very small. No water jets were used either inside or outside the monolith. Compressed air was used in the later stages of the anchorage monoliths on the Calcutta side.

(10) The New Hawkesbury River Railway Bridge at Sydney, New South Wales: The five big monoliths had to be sunk very deep in order to reach a sand foundation; they were sunk throughout their depth by opengrabbing, although compressed air was used to float them into position and to assist control during sinking through the very soft mud and silt. The small piers founded on rock were also sunk by dredging until compressed air had to be installed to excavate the rock.

Use was made of dewatering and also of water and air jets inside and outside the monoliths respectively, to assist sinking. In the final positioning of the monoliths, water was expelled from under the cutting edge by means of compressed air: the air-pressure was then suddenly released, resulting in the caisson sinking well into the coarse sand. The sand usually rose in the wells, however, an amount equivalent to twice the run. No kentledge appears to have been used. It was found that the jets on the outside of the caisson could be used to assist in controlling position. 
TABLE 1

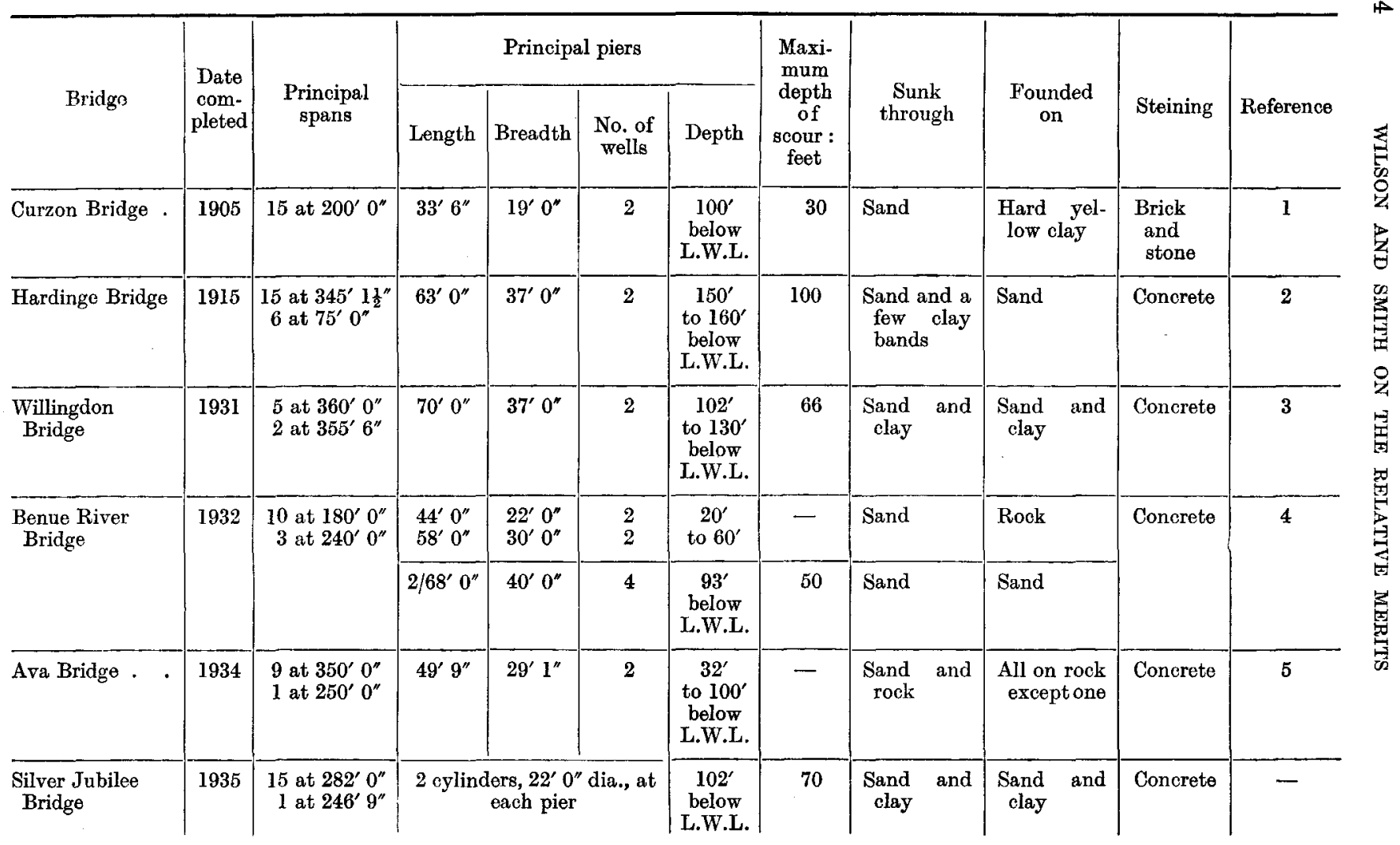




\begin{tabular}{|c|c|c|c|c|c|c|c|c|c|c|c|}
\hline $\begin{array}{l}\text { Lower Zambezi } \\
\text { Bridge }\end{array}$ & 1935 & $\begin{array}{r}33 \text { at } 262^{\prime} 6^{\prime \prime} \\
7 \text { at } 165^{\prime} 0^{\prime \prime}\end{array}$ & $\begin{array}{l}36^{\prime} 0^{\prime \prime} \\
28^{\prime} 9^{\prime \prime}\end{array}$ & $\begin{array}{l}20^{\prime} 0^{\prime \prime} \\
16^{\prime} 0^{\prime \prime}\end{array}$ & $\begin{array}{l}2 \\
2\end{array}$ & $\begin{array}{c}123^{\prime} \\
\text { to } 73^{\prime} \\
\text { below } \\
\text { L.W.L. }\end{array}$ & 60 & $\begin{array}{l}\text { Sand and a } \\
\text { little clay }\end{array}$ & $\begin{array}{l}\text { Rock, sand, } \\
\text { and clay }\end{array}$ & Concrete & 6 \\
\hline $\begin{array}{l}\text { San Francisco- } \\
\text { Oakland Bay } \\
\text { Bridge }\end{array}$ & 1936 & $\begin{array}{l}1 \text { cantilever } \\
\text { of } 1,400^{\prime} 0^{\prime \prime}\end{array}$ & 一 & - & - & $\begin{array}{c}228^{\prime} \\
\text { below } \\
\text { L.W.L. }\end{array}$ & - & $\begin{array}{l}\text { Mud, sand, } \\
\text { clay, and } \\
\text { rock }\end{array}$ & $\begin{array}{l}\text { Clay and } \\
\text { gravel }\end{array}$ & Concrete & 7 \\
\hline \multirow[t]{2}{*}{$\begin{array}{l}\text { New Howrah } \\
\text { Bridge }\end{array}$} & \multirow[t]{2}{*}{1942} & \multirow[t]{2}{*}{$\begin{array}{l}\text { Main span } \\
1,500^{\prime} 0^{\prime \prime}\end{array}$} & $2 / 18 l^{\prime} 6^{\prime \prime}$ & $81^{\prime} 6^{\prime \prime}$ & 21 & $\begin{array}{c}103^{\prime} \\
\text { below } \\
\text { ground }\end{array}$ & \multirow[t]{2}{*}{-} & \multirow[t]{2}{*}{$\begin{array}{l}\text { Silt, sand, } \\
\text { and clay }\end{array}$} & Clay & \multirow[t]{2}{*}{ Concrete } & \multirow[t]{2}{*}{8,9} \\
\hline & & & $4 / 54^{\prime} 0^{\prime \prime}$ & $27^{\prime} 0^{\prime \prime}$ & 2 & $\begin{array}{c}87^{\prime} \\
\text { below } \\
\text { ground }\end{array}$ & & & & & \\
\hline
\end{tabular}

References :-

1. R. R. Gales, "The Curzon Bridge at Allahabad." Min. Proc. Instn Civ. Engrs, vol. clxxiv (1907-8, Pt. 4), p. 1.

2. Sir Robert R. Gales, "The Hardinge Bridge over the Lower Ganges at Sara." Min. Proc. Instn Civ. Engrs, vol. ccv (1917-18, Pt. 1), p. 18.

3. Robert Mair, "The Willingdon Bridge, Calcutta." Min. Proc. Instn Civ. Engrs, vol. 235 (1932-33, Pt. 1), p. 36.

4. W. E. Thomas, "The Construction of a Bridge over the River Benue at Makurdi, Nigeria." Selected Engineering Paper No. 166, Instn Civ. Engrs, 1934.

5. G. G. T. Toller, "The Foundations of the Ava Bridge." Proc. Assoc. Engrs, Burma, vol. 7, 1935.

6. G. E. Howorth, "The Construction of the Lower Zambezi Bridge." J. Instn Civ. Engrs, vol, 4, p. 369 (Jan. 1937 ).

7. "Annual Progress Reports [six], San Francisco-Oakland Bay Bridge." Dept. of Pub. Wks, California, 1934-39.

8. A. M. Ward and Ernest Bateson, "The New Howrah Bridge, Calcutta : Design of the Structure, Foundations, and Approaches." J. Instn Civ. Engrs, vol. 28, p. 167 (May 1947).

9. G. E. Howorth and H. Shirley Smith, "The New Howrah Bridge, Caloutta : Construction." Ibid., p. 211.

10. A. C. Fewtrell, "The New Hawkesbury River Railway Bridge, New South Wales, Australia." J. Instn Civ. Engrs, vol. 32 , p. 419 (Oct. 1949). 


\section{RÉSUMÉ}

Rule-of-thumb recommendations would be out of place in discussing a subject as many-sided as that of bridge foundations, but the following summary of the foregoing remarks may be given :-

(1) Compressed air is an invaluable asset in sinking bridge foundations but, in view of its cost, pneumatic sinking should not be adopted to the exclusion of sinking by open dredging unless the particular conditions make its use essential.

(2) The only limitation to the method of open grabbing is that the ground must be of a kind that can satisfactorily be grabbed. The method can be used at depths where pneumatic sinking could not be considered. It is, in fact, the only method that can be used for very deep foundations.

(3) In long bridges with many piers, some of which are founded on rock, it will probably pay to carry out the sinking by open dredging whereever possible and to make provison for applying compressed air for rock excavation.

(4) Compressed air may also be effectively used in the flotation and to assist in the control of deep monoliths designed to be sunk by open dredging to depths beyond the limits of pneumatic sinking.

\section{Discussion}

Mr H. Shirley Smith opened the Discussion with a summary of the principles and advantages of open grabbing as described in his Note, adding that a diver could be employed, if desired, to inspect the bottom before the concrete plug was placed. When founding in sand it was unnecessary, but in other materials it might be a useful check.

Compressed air, he maintained, was not a remedy for every trouble; in fact, it was when compressed air was put on that trouble often began. He had had to go into a pneumatic caisson three times in one day, when it had shown a tendency to tilt and had to be corrected. There were numerous instances of pneumatic caissons plunging. Occasionally the monolith plunged as well, but there were no men inside it to be drowned.

He referred to a system which he believed was due to the late $\mathrm{Mr}$ Fereday and which had first been used on the Kalabagh bridge in India. That consisted of sinking by open dredging as far as possible, and then, if the caisson had to be founded on rock which could not be dredged, putting a lid on top of the working chamber and applying compressed air for the 